\title{
Modern Aspects of Industrial Enterprises' Production Efficiency Management
}

\author{
Mykhailo Vedernikov \\ Department of Personnel Management \\ and Labour Economics \\ Khmelnytsky National University \\ Khmelnitsky, Ukraine \\ arh.mihael@gmail.com
}

Maria Zelena

Department of Personnel Management and Labour Economics

Khmelnytsky National University

Khmelnitsky, Ukraine

mariaverde4@ukr.net

\author{
Oksana Chernushkina \\ Department of Personnel Management \\ and Labour Economics \\ Khmelnytsky National University \\ Khmelnitsky, Ukraine \\ Chernushkina_OO@meta.ua
}

\author{
Lesia Volianska-Savchuk \\ Department of Personnel Management \\ and Labour Economics \\ Khmelnytsky National University \\ Khmelnitsky, Ukraine \\ liberty_lvs@ukr.net
}

Abstract - The article summarizes theoretical generalization and proposes to solve the scientific problem of improving the methodological and practical foundations of industrial production management. The purpose of the article is to substantiate the priority of the role of productivity theory in the economic management system, the necessity of introducing its criteria and the application of a systematic approach to the management of production productivity. The priority is given to the role of the theory of productivity in the economic management system, the need to introduce its criteria. The scientific novelty of the obtained results is to improve the methodology of research of the economic category 'production productivity', in particular: its content, criteria, systems of indicators that will allow to evaluate the efficiency and optimality of the use of production resources, the possibility of achieving the enterprise profitability and economic stability. The article proposes a production performance management model that considers the production process as a flow, connecting the internal and external environments of the enterprise. The state of production productivity at the leading industrial enterprises of Ukraine has been analyzed. Object of the research is production productivity, its criteria, system of indicators of evaluation of efficiency and optimization of the use of production resources, ensuring competitive functioning of enterprises. Research methods. General scientific methods of research are applied in the article, in particular: systematic approach - in reflection of the state of the theory of production productivity; statistical and economic analysis - in assessing the economic performance of enterprises and the impact of key factors on productivity dynamics.

Keywords - theory of productivity, production efficiency, performance criteria, performance management

\section{INTRODUCTION}

It is a well-known fact that, the progressiveness of the structure of the national economy is characterized by a protracted development of industrial production. The Ukrainian economy has always been based on high-tech industries, a strong engineering and scientific base, and a sufficient supply of highly skilled personnel. However, the share of industry in the total production of Ukraine in recent times is about twenty-five percent (Table 1) [1-3].
The given data show that along with the positive, at first glance, tendency to the increase of the volume of industrial sold products there is a decrease in the number of employees in industry and its share in total number of employees, unstable financial result of activity of industrial enterprises and in general, decrease of capital investments in industry.

TABLE I. INDICATORS FOR MEASURING THE PRODUCTIVITY

\begin{tabular}{|c|c|c|c|c|c|c|}
\hline Indicator & 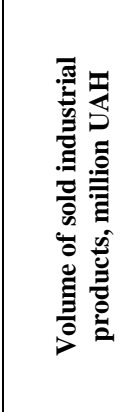 & 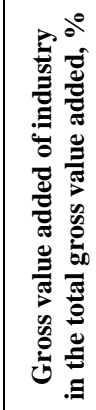 & 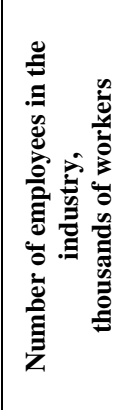 & 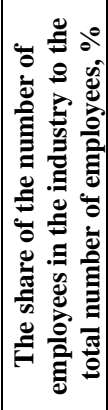 & 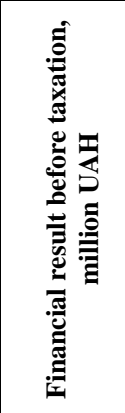 & 总 \\
\hline 2011 & 1331887.6 & 25.2 & 3123.5 & 35.66 & 58662.3 & 34.3 \\
\hline 2012 & 1400680.2 & 24.8 & 3126.9 & 36.27 & 21353.4 & 35.2 \\
\hline 2013 & 1354130.1 & 22.7 & 3019.5 & 36.47 & 13698.3 & 39.4 \\
\hline 2014 & 1428839.1 & 23.5 & 2506.8 & 35.31 & -166414.0 & 39.3 \\
\hline 2015 & 1776603.7 & 23.6 & 2314.6 & 35.13 & -181360.9 & 32.1 \\
\hline 2016 & 2158030.0 & 25.0 & 2254.4 & 34.17 & -7569.9 & 33.3 \\
\hline 2017 & 2625862.7 & 25.1 & 1944.7 & 24.05 & 87461.7 & 33.1 \\
\hline 2018 & 2508579.5 & 23.2 & 1906.4 & 23.69 & 103790.5 & 34.14 \\
\hline
\end{tabular}

Thus, the priority of political processes over economic, external influences, general instability, financial crisis and imperfection of the legislative framework negatively affect the state of industrial development in Ukraine. There is a need to introduce new approaches to understanding the processes of economic development, the introduction of systematic workings out in the field of productivity in the practice of economic activity.

The main tendencies in the change in the gross value added of industry in the total gross value added, the share of the number of employees in the industry to the total number 
of employees and capital investments in the industry are shown in Fig. 1

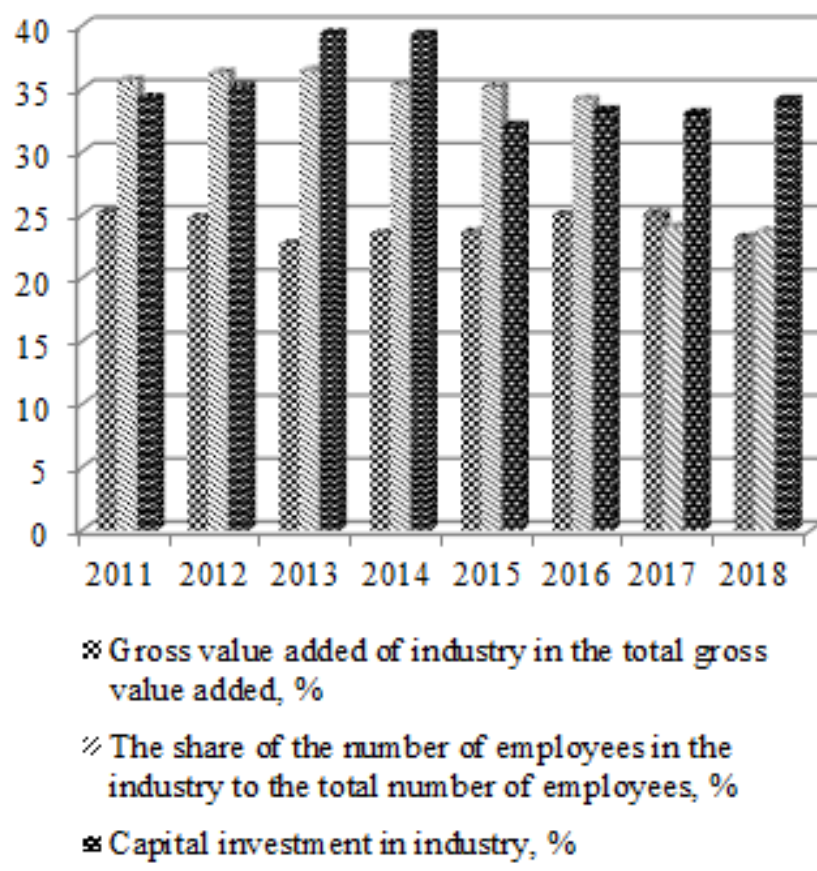

Fig. 1. Dynamics of the main indicators of industrial development of Ukraine

\section{ANALYSIS OF RECENT RESEARCHES AND PUBLICATIONS}

Issues of productivity, management of production efficiency and the search for ways to its increase have been considered in the works by $[3,4,5,6,7]$.

Most foreign scientific publications concern the problem of interpreting the essence of productivity and substantiating its measurement indicators $[8,9,10,11]$. All scientists value productivity as a fundamental factor in improving living standards. Productivity growth, they believe [12], is accompanied by an increase in the production potential of the economy, that is, the maximum level of production that can be obtained taking into account the available labor, capital, resources and modern technologies. Productivity is considered to be a key source of economic growth and competitiveness and serves as the main statistical information for many international comparisons and the assessment of country development indicators [6].

It is offered to investigate the productivity of foreign scientists at the firm level (micro level), where the generation and application of technological and organizational knowledge (innovations) are the main factors of productivity growth, and at the national level (macro level). In their belief, the increase in productivity at the firm level is directly transformed into national economic growth [11].

In all scientific developments, productivity is considered as the ratio of the indicator of total results to the expense indicator used in the production of goods and services. Among the performance indicators used, the most common are multi-factor productivity, which measures the growth of value added per unit labor and capital employed, and labor productivity, which measures the growth of value added production per unit of labor used [12, 13].
The authors present their own methodology [13] for calculating multi-factor productivity, in which the productivity of the production system is offered to be calculated from the standpoint of expected productivity, expected productivity bill, expected productivity of materials and expected capital productivity.

However, in some researches, foreign scientists consider the productivity of the production system in terms of increasing production capacity [10]. A set of practical strategies that can be used to increase the throughput and capacity of production systems in accordance with the needs of each production system is proposed. Other scholars are convinced that labor productivity is the source of mediumand long-term economic growth. It is noted in the characteristic of the main developed countries of the world tendencies of slowing down of productivity, which is due to slowing down the combined factor productivity [12]

In addition to studying the problem of establishing the essence of the notion of productivity and defining indicators of its measurement, foreign scientists raise the issue of the interconnected influence of external and internal factors of production and economic systems on productivity.

Thus, in [12], the authors emphasize a positive increase in productivity from multinational production. It is noted that countries with greater openness to multinational production demonstrate, on average, higher aggregate productivity and faster economic growth. Greater openness to multinational production leads to more stringent competition, which can lead to a redistribution of resources in every domestic firm, from domestic to foreign multinational firms and from less productive to more productive firms. Equally important for the study of foreign scientists, the influence of wages, in particular the introduction of the national minimum wage, on the productivity of the firm is chosen by the firm $[8,11]$. As the minimum wage, they say, increases the cost of labor, companies can switch to more capital intensive forms of production, introduce organizational changes, or offer training to improve productivity.

However, methodological principles, quantitative methods of evaluation and performance modeling have not yet been adequately justified in terms of the systematic approach to the rational combination of various factors of production under conditions of uncertainty in the environment of the functioning of an enterprise as a complex socio-economic system.

The purpose of the article is to justify the role of the theory of productivity in the economic system of management, the need to implement its criteria and the application of a systematic approach to the management of productivity of production.

\section{MAIN RESULTS OF THE RESEARCH}

The basis for the development of the concept of productivity should become a peculiar synthesis of studies on the optimal use of resources in terms of their deficit as the basic postulate of the theory of optimality and domestic developments in the theory of efficiency. The criterion of productive management is to consider the growth of human development, the improvement of well-being and the development of members of society. 
It is justified to use the static and dynamic approaches to the analysis of productivity of production in order to specify the forms of productivity. To quantitatively measure the productivity of production, you need to use the concept of a single indicator with the possibility of constructing partial performance indicators. Moreover, it is justified to use precisely the expense indicator, which is devoid of methodological problems of calculation.

To the system of performance criteria, which fully reflects the level of productivity of the enterprise's economic activity, we include: efficiency, profitability, efficiency, optimality, competitiveness of production, stability.

Profitability and efficiency as criteria of productivity of the economic system characterize the effectiveness of its functioning from the inside - in terms of organization of the production process. Effectiveness should be considered the degree of use of various types of resources for the economic activity of the economic system. The experience of constructing a system of indicators for measuring the state of using resources at the local level is sufficiently developed in the theory of efficiency. Profitability is the ratio between the financial results obtained and the total costs incurred by enterprises in the course of their activities.

In the conditions of implementation of the above criteria, it is necessary to talk about the effectiveness of the production process and the possibility of achieving the state of efficiency and optimality of the economy by the economic system. Efficiency is the degree to which the economic system achieves its goals. In order to assess the level of effectiveness, it is necessary to take into account the timeliness of the achievement of these goals. Ideally, you should understand the level of use of the system for operating costs. Optimality is determined by comparing the resources intended to be used to achieve certain goals, with the resources that were actually consumed.

The conditions for the stability of the functioning of the economic system include the implementation of all performance criteria, not only in a specific period of time, but also the achievement of sustained performance of the system over a long period of time. Therefore, criteria of productivity of economic activity of the enterprise should be considered in the dynamics, with the identification of trends and the formation of a program of measures for the adoption of certain decisions to eliminate negative phenomena. Only if the above criteria are fully implemented can we talk about the performance of the functioning of the economic system as a whole.

Causal and consequential connections in the system of performance criteria can be illustrated by the scheme (Fig. 2).

In the theory of productivity, the notion of productivity management is a decisive place i.e. a process based on the strategic and operational planning of the organization of production, the motivation of staff to perform productive activity, measuring, analyzing and controlling the level of productivity of production.

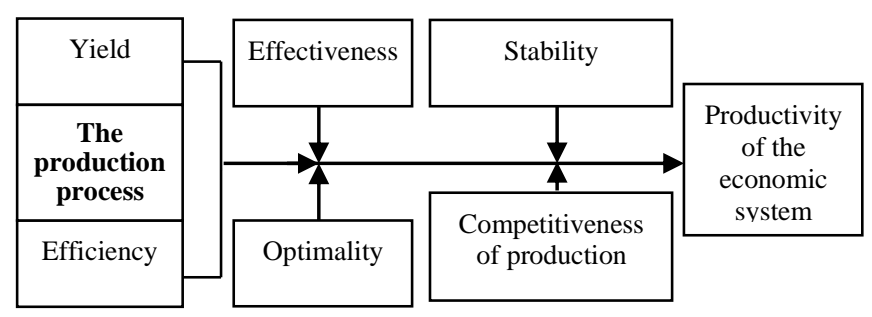

Fig. 2. Causal and consequential connections in the system of criteria of productivity of the economic system

The flow of resources in the process of managing the performance can be represented by a scheme (Fig. 3).

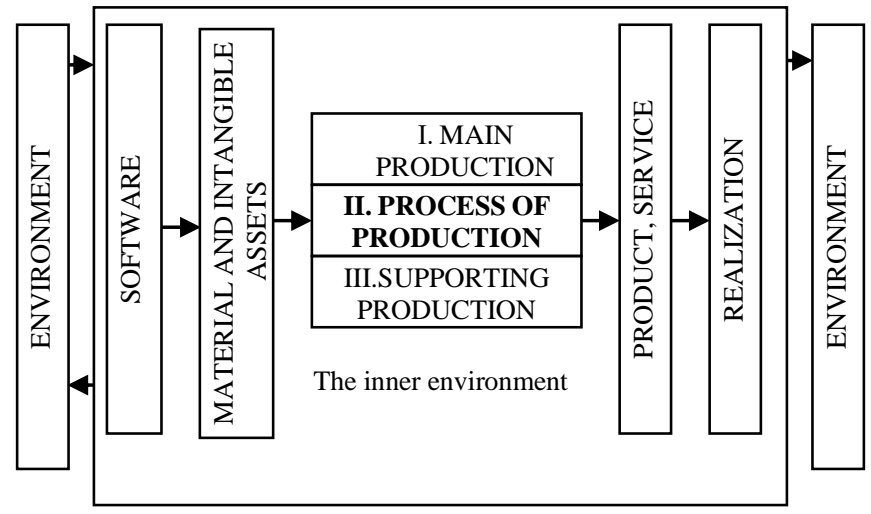

Fig. 3. Flow of resources in the process of productivity management

The environment of the operation of the enterprise is internal. The hosting system provides itself with resources. In the process of production, in which the main and auxiliary production is involved, the products of the enterprise (goods or services) are manufactured. In the process of ensuring the production of resources and sales of its products, the management system is in contact with the external environment.

Summarizing the results of the study of the theory of productivity, a critical analysis of the work of other authors, we offer our own model of management of the productivity of the economic system (Fig. 4).

Planning as an integral part of a system is a process of determining the state and dynamics of productivity that an enterprise intends to achieve over a certain period, as well as the means, ways and conditions for their achievement. Performance planning is conditioned by the systems used by enterprises for performance indicators and measurement systems. To assess the state and dynamics of the performance of the economic system, comparing its achievements with the achievements of other systems and finding reserves increase should be applied analysis and control of the performance of the economic entity. Depending on the target results, determine which indicators need to be investigated, how they should be correlated with each other, and what measurement is needed to arrive at the final conclusions $[14,15]$.

To conduct research, we selected the leading industrial enterprises of Ukraine: Enterprise «Y», whose activities are characterized by high rates of development, Enterprise «H» with an average growth rate of activity and Enterprise «T» with low rates of development, whose activities in certain periods are unprofitable. 


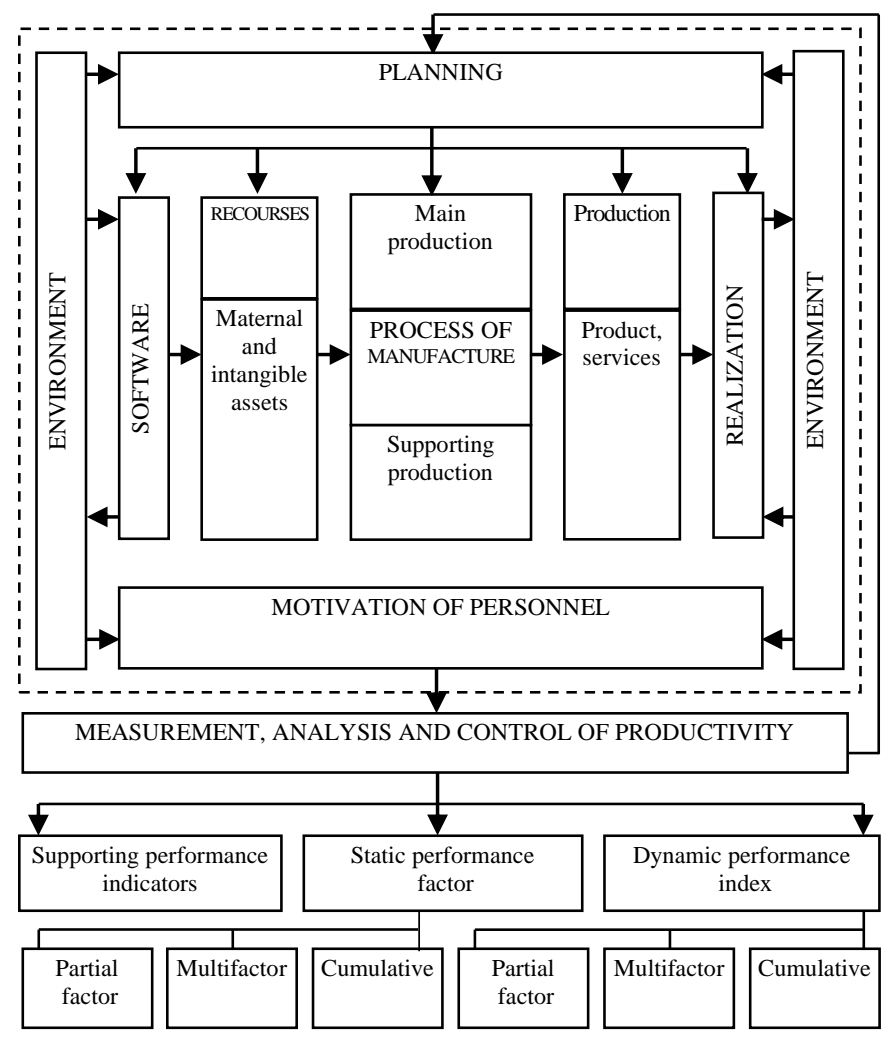

Fig. 4. Model of productivity management

Indicators for measuring the productivity of production by the criterion of efficiency and traditional indicators of the assessment of the efficiency of enterprises are shown in Table 2 and Table 3 .

The system for measuring the productivity of production should be individualized and determined by the main purpose of the analysis. Measuring well-developed and used in practice includes normative performance measurement (NPM), multi-factor performance measurement (MFPM), and multi-criteria performance measurement (MCPM). The method of nominal groups (MNG) and the Delphic method (DM) are used in one of the stages of the use of MFPM.

To assess the overall economic condition of the economic system, it is necessary to apply a whole system of meters, which will determine the level and dynamics of the productivity of the economic system, establish a quantitative relationship of productivity with other economic processes and phenomena, compare the levels and dynamics of productivity of this enterprise with others, identify reserves and develop productivity enhancement programs.

Due to the target orientation of the construction of performance meters, it is possible to develop sufficiently small system of measuring the productivity and reduce them to a larger aggregated system at the enterprise level. In this case, the performance measurement systems will function in a decentralized way in the divisions.

Knowledge of factors of productivity increase, ability to determine their influence on performance indicators can influence the level of indicators and their dynamics. Most researchers analyze the possibility of increasing the efficiency of production based on the use of factors that increase the productivity of living labor, material and fund.
TABLE II. INDICATORS FOR MEASURING THE PRODUCTIVITY

\begin{tabular}{|c|c|c|c|c|c|c|c|c|}
\hline \multirow[b]{2}{*}{ Indicator } & \multicolumn{7}{|c|}{ Year } & \multirow[b]{2}{*}{\begin{tabular}{|c|} 
Growth \\
rate, \% \\
$2017 /$ \\
2011
\end{tabular}} \\
\hline & 2011 & 2012 & 2013 & 2014 & 2015 & 2016 & 2017 & \\
\hline \multicolumn{9}{|c|}{ Enterprise « $\mathrm{Y} »$} \\
\hline \multicolumn{9}{|c|}{ Performance indicators for the use of fixed assets } \\
\hline $\begin{array}{l}\text { Productivity } \\
\text { of fixed assets, } \\
\text { UAH. }\end{array}$ & 73.32 & 69.72 & 155.95 & 116.71 & 66.60 & 45.85 & 65.92 & 89.91 \\
\hline $\begin{array}{l}\text { Cost share in total } \\
\text { production costs, } \\
\%\end{array}$ & 1.45 & 1.56 & 1.06 & 1.49 & 1.72 & 2.28 & 1.75 & 121.34 \\
\hline $\begin{array}{l}\text { Profitability of } \\
\text { fixed assets, \% }\end{array}$ & 266.68 & 503.83 & 5048.9 & 4217.4 & 881.64 & 344.8 & 943.62 & 353.85 \\
\hline \multicolumn{9}{|c|}{ Indicators of the effectiveness of the use of material resources } \\
\hline $\begin{array}{l}\text { Productivity } \\
\text { of material } \\
\text { resources, UAH. }\end{array}$ & 1.42 & 1.50 & 2.30 & 2.41 & 1.57 & 1.37 & 1.51 & 106.48 \\
\hline $\begin{array}{l}\text { Cost share in total } \\
\text { production } \\
\text { costs, } \%\end{array}$ & 74.58 & 72.37 & 72.09 & 71.94 & 72.84 & 76.38 & 76.42 & 102.46 \\
\hline $\begin{array}{l}\text { Profitability of } \\
\text { material } \\
\text { resources, \% }\end{array}$ & 5.17 & 10.86 & 74.41 & 87.17 & 20.79 & 10.28 & 21.66 & 419.06 \\
\hline \multicolumn{9}{|c|}{ Indicators of the efficiency of human resources use } \\
\hline $\begin{array}{l}\text { Productivity of } \\
\text { human resources, } \\
\text { UAH. }\end{array}$ & 4.42 & 4.17 & 6.17 & 6.53 & 4.50 & 4.89 & 5.30 & 119.81 \\
\hline $\begin{array}{l}\text { Cost share in total } \\
\text { production } \\
\text { costs, } \%\end{array}$ & 23.97 & 26.07 & 26.85 & 26.57 & 25.45 & 21.34 & 21.83 & 91.06 \\
\hline $\begin{array}{l}\text { Profitability } \\
\text { of human } \\
\text { resources, \% }\end{array}$ & 16.08 & 30.14 & 199.79 & 236.04 & 59.51 & 36.79 & 75.82 & 471.50 \\
\hline \multicolumn{9}{|c|}{ Enterprise $« \mathrm{H} »$} \\
\hline \multicolumn{9}{|c|}{ Performance indicators for the use of fixed assets } \\
\hline $\begin{array}{l}\text { Productivity } \\
\text { of fixed assets, } \\
\text { UAH. }\end{array}$ & 51.08 & 51.89 & 39.00 & 50.45 & 87.24 & 30.19 & 43.35 & 84.88 \\
\hline $\begin{array}{l}\text { Cost share in total } \\
\text { production costs, } \\
\%\end{array}$ & 2.27 & 2.10 & 2.76 & 2.10 & 1.20 & 2.93 & 2.62 & 115.60 \\
\hline $\begin{array}{l}\text { Profitability of } \\
\text { fixed assets, } \% \\
\end{array}$ & 314.51 & 38.76 & 131.16 & 303.43 & 688.18 & - & 282.31 & 89.76 \\
\hline \multicolumn{9}{|c|}{ Indicators of the effectiveness of the use of material resources } \\
\hline $\begin{array}{l}\text { Productivity of } \\
\text { material } \\
\text { resources, UAH. }\end{array}$ & 2.27 & 2.13 & 2.29 & 2.22 & 1.97 & 1.85 & 2.57 & 112.98 \\
\hline $\begin{array}{l}\text { Cost share in total } \\
\text { production costs, } \\
\%\end{array}$ & 51.07 & 51.32 & 46.99 & 47.68 & 53.13 & 47.91 & 44.36 & 86.86 \\
\hline $\begin{array}{l}\text { Profitability of } \\
\text { material } \\
\text { resources, \% }\end{array}$ & 13.98 & 1.59 & 7.71 & 13.34 & 15.57 & - & 16.71 & 119.47 \\
\hline \multicolumn{9}{|c|}{ Indicators of the efficiency of human resources use } \\
\hline $\begin{array}{l}\text { Productivity of } \\
\text { human resources, } \\
\text { UAH. }\end{array}$ & 2.49 & 2.34 & 2.14 & 2.11 & 2.30 & 1.80 & 2.15 & 86.36 \\
\hline $\begin{array}{l}\text { Cost share in total } \\
\text { production costs, } \\
\%\end{array}$ & 46.66 & 46.58 & 50.25 & 50.22 & 45.67 & 49.16 & 53.02 & 113.63 \\
\hline $\begin{array}{l}\text { Profitability } \\
\text { of human } \\
\text { resources, \% }\end{array}$ & 15.31 & 1.75 & 7.21 & 12.67 & 18.11 & - & 13.98 & 91.32 \\
\hline \multicolumn{9}{|c|}{ Enterprise $\langle\mathrm{T}\rangle$} \\
\hline & Perfo & mance i & dicators & or the us & of fixed & assets & & \\
\hline $\begin{array}{l}\text { Productivity of } \\
\text { fixed assets, } \\
\text { UAH. }\end{array}$ & 15.91 & 16.47 & 5.90 & 14.53 & 14.08 & 11.30 & 18.27 & 114.81 \\
\hline $\begin{array}{l}\text { Cost share in total } \\
\text { production } \\
\text { costs, } \%\end{array}$ & 6.86 & 6.28 & 10.48 & 8.47 & 5.49 & 8.17 & 5.07 & 73.85 \\
\hline $\begin{array}{l}\text { Profitability of } \\
\text { fixed assets, \% }\end{array}$ & 118.68 & 66.30 & - & 84.45 & - & 14.35 & 142.43 & 120.00 \\
\hline \multicolumn{9}{|c|}{ Indicators of the effectiveness of the use of material resources } \\
\hline $\begin{array}{l}\text { Productivity of } \\
\text { material esources, } \\
\text { UAH. }\end{array}$ & 1.97 & 1.71 & 1.20 & 2.12 & 1.43 & 2.45 & 1.73 & 87.98 \\
\hline $\begin{array}{l}\text { Cost share in total } \\
\text { production } \\
\text { costs, \% }\end{array}$ & 55.52 & 60.37 & 51.66 & 58.05 & 54.11 & 37.64 & 53.51 & 96.37 \\
\hline $\begin{array}{l}\text { Profitability of } \\
\text { material } \\
\text { resources, \% }\end{array}$ & 14.67 & 6.90 & - & 12.32 & - & 3.11 & 13.49 & 91.96 \\
\hline \multicolumn{9}{|c|}{ Indicators of the efficiency of human resources use } \\
\hline $\begin{array}{l}\text { Productivity of } \\
\text { human resources, } \\
\text { UAH. }\end{array}$ & 2.90 & 3.10 & 1.63 & 3.67 & 1.91 & 1.70 & 2.24 & 76.99 \\
\hline $\begin{array}{l}\text { Cost share in total } \\
\text { production } \\
\text { costs, } \%\end{array}$ & 37.62 & 33.35 & 37.86 & 33.48 & 40.39 & 54.19 & 41.43 & 110.13 \\
\hline $\begin{array}{l}\text { Profitability } \\
\text { of human } \\
\text { resources, \% }\end{array}$ & 21.65 & 12.48 & - & 21.36 & - & 2.16 & 17.42 & 80.47 \\
\hline
\end{tabular}


Author [3, 4] which distinguish structural changes, natural resources, government structures and infrastructures among internal factors. The internal ones include firm and soft factors. The division of factors of productivity increase of production into internal and external ones.

According to the results of the calculation of productivity indicators for all investigated enterprises, the productivity of fixed assets is the highest, which at the enterprises «Y» and the enterprises «H» has an unstable tendency to increase, while in the enterprise «T» a tendency decreases. Indicators of productivity of material and human resources during 2011-2017 are characterized by a steady decline.

The negative activity of enterprises for the investigated period is, in general, the predominant decrease in the productivity of human resources compared with other indicators.

TABLE III. TRADITIONAL INDICATORS FOR ASSESSING THE PERFORMANCE OF ENTERPRISES

\begin{tabular}{|c|c|c|c|c|c|c|c|c|}
\hline \multirow{2}{*}{ Indicator } & \multicolumn{7}{|c|}{ Year } & \multirow{2}{*}{$\begin{array}{r}\text { Growth } \\
\text { rate, \% } \\
2017 / \\
2011 \\
\end{array}$} \\
\hline & 2011 & 2012 & 2013 & 2014 & 2015 & 2016 & 2017 & \\
\hline \multicolumn{9}{|c|}{ Enterprise «Y»» } \\
\hline $\begin{array}{l}\text { Labor productivity of } \\
\text { an employee, ths. } \\
\text { UAH. }\end{array}$ & 228.01 & 258.46 & 615.15 & 785.65 & 542.51 & 445.78 & 763.97 & 335.05 \\
\hline $\begin{array}{l}\text { Capacity of production, } \\
\text { UAH. }\end{array}$ & 0.84 & 0.78 & 0.54 & 0.51 & 0.75 & 0.83 & 0.74 & 87.68 \\
\hline $\begin{array}{l}\text { Cost-effectiveness of } \\
\text { net profit, \% }\end{array}$ & 4.32 & 9.25 & 59.77 & 71.42 & 17.72 & 9.05 & 19.39 & 448.88 \\
\hline $\begin{array}{l}\text { Capital return on fixed } \\
\text { assets, UAH. }\end{array}$ & 4.17 & 4.47 & 9.64 & 10.81 & 6.61 & 5.01 & 7.21 & 172.79 \\
\hline \multicolumn{9}{|c|}{ Enterprise «H» } \\
\hline $\begin{array}{l}\text { Labor productivity of } \\
\text { an employee, ths. UAH }\end{array}$ & 134.48 & 149.81 & 144.63 & 178.60 & 298.07 & 202.17 & 372.04 & 276.64 \\
\hline $\begin{array}{l}\text { Capacity of production, } \\
\text { UAH. }\end{array}$ & 0.77 & 0.82 & 0.81 & 0.84 & 0.83 & 0.82 & 0.70 & 90.21 \\
\hline $\begin{array}{l}\text { Cost-effectiveness of } \\
\text { net profit, \% }\end{array}$ & 7.99 & 0.91 & 4.13 & 7.20 & 9.53 & - & 9.36 & 117.23 \\
\hline $\begin{array}{l}\text { Capital return on fixed } \\
\text { assets, UAH. }\end{array}$ & 2.61 & 4.71 & 4.48 & 5.97 & 12.65 & 7.15 & 12.74 & 487.16 \\
\hline \multicolumn{9}{|c|}{ Enterprise «T» } \\
\hline $\begin{array}{l}\text { Labor productivity of } \\
\text { an employee, ths. } \\
\text { UAH. }\end{array}$ & 193.80 & 238.05 & 116.22 & 622.25 & 231.56 & 200.33 & 346.66 & 178.88 \\
\hline $\begin{array}{l}\text { Capacity of production, } \\
\text { UAH. }\end{array}$ & 0.74 & 0.77 & 0.76 & 0.78 & 0.82 & 0.76 & 0.73 & 99.14 \\
\hline $\begin{array}{l}\text { Cost-effectiveness of } \\
\text { net profit, \% }\end{array}$ & 10.12 & 5.20 & - & 7.44 & - & 1.66 & 10.67 & 105.43 \\
\hline $\begin{array}{l}\text { Capital return on fixed } \\
\text { assets, UAH. }\end{array}$ & 4.01 & 5.21 & 1.54 & 7.79 & 3.29 & 3.13 & 6.09 & 152.16 \\
\hline
\end{tabular}

If to use traditional indicators of evaluating the effectiveness of an enterprise, such as labor productivity, product flow rate, cost-effectiveness and return on assets, the characteristics of the economic activity of the enterprises under study appear to be rather positive: the labor productivity of the employee as the main indicator of the efficiency of staff utilization at the enterprise for the period 2011-2017 has increased almost 3.5 times at the Enterprise «Y», 3 times at the Enterprise «N», 2 times at the Enterprise «T».

The calculations have shown that traditional indicators of evaluating the performance of enterprises do not always reflect actual business trends. Therefore, only the fundamentals of productivity theory combined with the synergetic methodology are crucial for a reliable assessment of the quality of production and the identification of trends in socio-economic development in order to search for productivity growth reserves.

The processes of effective management of production productivity will be facilitated by the possibility of making predictive calculations of both partial factor productivity indices and the indicator of aggregate productivity of production.

It is expedient to predict productivity according to the factor model of total performance of production (TP), which has the form:

$$
T P=\frac{\lambda^{\Pi}+\frac{1}{\lambda^{M}}+\frac{1}{\lambda^{B \Pi}}+\frac{1}{\lambda^{A}}}{\lambda^{H A}+\lambda^{O A}}
$$

where $\lambda^{\Pi}$ is profitability of sold products; $\lambda^{M}$ is productivity of material resources; $\lambda^{B \Pi}$ is productivity of human resources; $\lambda^{A}$ is productivity of fixed assets; $\lambda^{H A}$ is capital intensity over non-working capital; $\lambda^{O A}$ is capital intensity on working capital.

Our proposed methodology for the analysis of the total productivity of production involves the expansion of the original formulas for calculating the indicator for all qualitative and quantitative characteristics of the intensification of production and increase the effectiveness of economic activity.

The model of aggregate productivity of production will reveal the interdependence of the constituent elements: the indicator of profitability of sold products, the capital intensity of irreversible and working capital, the partial factor indicators, and the indicator of aggregate productivity of the entity, to assess their impact on the dynamics of productivity.

The generalized results of the factor analysis of the total productivity of production by the factor model are presented in Table 4.

According to the results of calculations, the most influential were the indicators of capital intensity for noncurrent and working capital, which almost throughout the investigated period have a positive effect on the aggregate productivity of such enterprises as Enterprise "Y» and Enterprise $« \mathrm{~N} »$, and negatively - Enterprise $\langle\mathrm{T} »$.

The least influential is the performance of fixed assets, which has an unstable tendency to influence the productivity of the enterprises under study. In addition, the factor analysis of the aggregate productivity of production allows determining the priority effect of individual indicators on the dynamics of productivity in specific years of research.

Thus, the decline in the indicator of total productivity of the «Y» Enterprise in 2014 was mainly due to the negative impact of the capital intensity on working capital, and in 2015 - the profitability of sales. A significant increase in the total productivity of the «N» Enterprise in 2015 and its decrease in 2016 became possible due to the dynamics of capital intensity for working capital and non-working capital. 
TABLE IV. ABSOLUTE DEVIATIONS OF INDICATORS OF THE MODEL OF AGGREGATE PRODUCTIVITY OF PRODUCTION

\begin{tabular}{|c|c|c|c|c|c|c|c|c|}
\hline \multicolumn{2}{|c|}{ Indicator } & 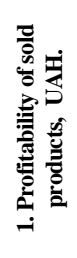 & 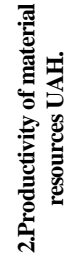 & 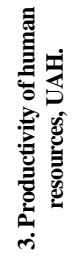 & 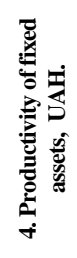 & 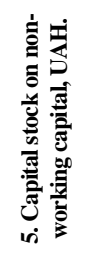 & 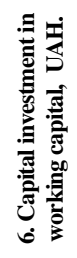 & 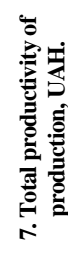 \\
\hline \multirow{6}{*}{ 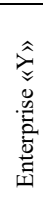 } & 2012 & 0.066 & -0.070 & 0.025 & 0.001 & 0.058 & -0.073 & 0.007 \\
\hline & 2013 & 0.459 & -0.421 & -0.142 & -0.014 & 0.491 & 0.297 & 0.670 \\
\hline & 2014 & 0.101 & -0.055 & -0.024 & 0.006 & 0.077 & -0.544 & -0.439 \\
\hline & 2015 & -0.499 & 0.484 & 0.151 & 0.014 & -0.250 & -0.389 & -0.489 \\
\hline & 2016 & -0.088 & 0.146 & -0.028 & 0.010 & -0.111 & 0.247 & 0.176 \\
\hline & 2017 & 0.114 & -0.118 & -0.026 & -0.011 & 0.196 & 0.441 & 0.596 \\
\hline \multirow{6}{*}{ 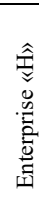 } & 2012 & -0.080 & 0.044 & 0.036 & 0.000 & 0.452 & 0.062 & 0.513 \\
\hline & 2013 & 0.053 & -0.068 & 0.082 & 0.013 & -0.051 & 0.003 & 0.032 \\
\hline & 2014 & 0.053 & 0.029 & 0.016 & -0.012 & 0.391 & 0.083 & 0.559 \\
\hline & 2015 & 0.046 & 0.138 & -0.096 & -0.021 & 0.480 & 0.855 & 1.402 \\
\hline & 2016 & -0.345 & 0.130 & 0.450 & 0.081 & -0.803 & -1.515 & -2.002 \\
\hline & 2017 & 0.131 & -0.254 & -0.150 & -0.017 & 0.155 & 0.580 & 0.444 \\
\hline \multirow{6}{*}{ 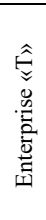 } & 2012 & -0.037 & 0.082 & -0.024 & -0.002 & 0.124 & -0.011 & 0.131 \\
\hline & 2013 & -0.165 & 0.301 & 0.347 & 0.130 & -0.704 & -0.482 & -0.572 \\
\hline & 2014 & 0.065 & -0.152 & -0.142 & -0.042 & 0.143 & 1.352 & 1.225 \\
\hline & 2015 & -0.194 & 0.487 & 0.534 & 0.005 & -0.715 & -0.828 & -0.711 \\
\hline & 2016 & 0.041 & -0.266 & 0.059 & 0.016 & -0.008 & -0.196 & -0.354 \\
\hline & 2017 & 0.047 & 0.123 & -0.101 & -0.024 & 0.114 & 0.252 & 0.410 \\
\hline
\end{tabular}

The decline in the «T» Enterprise total productivity indicator in 2013, 2015, and 2016 was curtailed due to the positive effect of the partial factor productivity indicators.

Thus, the results of the factor analysis of the productivity of the enterprises under investigation indicate the need for implementation of the practice of assessing the productivity of the activity and the use of partial factor indicators for analysis and improvement of productivity of management.

\section{CONCLUSIONS}

Modern conditions of the management of industrial enterprises require the achievement of the effectiveness of the activities and increase its level on the basis of the efficiency of the use of corporate resources.

The analysis of scientific researches of theories of efficiency and optimality proves the necessity of forming a concept of productivity, the criteria of which are efficiency, profitability, effectiveness, optimality, competitiveness of production, stability of functioning. In productivity theory, the key is the issue of productivity management, based on the strategic and operational planning of the organization of production, the motivation of the personnel to perform productive activity, measuring, analyzing and controlling the level of productivity of production.
The increase of production performance contributes to the growth of personal income of employees, makes it possible to coordinate production activities with the established strategic priorities, as a result - the economic indicators improve. The system approach to solving the problem of productivity increase requires the development of an adequate effective mechanism as a holistic and self-sufficient system with the interconnections between its elements.

\section{REFERENCES}

[1] Industry of Ukraine in 2011-2015. (2016, Jan. 16) State Statistics Service. [Online]. Available: http://www.ukrstat.gov.ua. Accessed on: June 10, 2019.

[2] Official site of the State Statistics Service of Ukraine. [Online]. Available: http://www.ukrstat.gov.ua. Accessed on: July 12, 2019.

[3] I.I. Prokopenko, Management Performance, Kyiv, Ukraine: Technics, 1990.

[4] V.O. Yeremenko, Productivity Improvement: Theory, Experience, Way of Ukraine, Kramatorsk, Ukraine: Publishing House of the Productivity Center of the Ministry of Labor and Social Policy of Ukraine, 2000.

[5] A. J. Field, Manufacturing Productivity and U.S. Economic Growth. Oxford, England: Oxford University Press, 2018.

[6] G.S. Rawat, A. Gupta and C. Juneja, "Productivity measurement of manufacturing system," Materials Today, vol.5, iss. 1, pp. 1483-1489, 2018 .

[7] L. Alfaro and M. X. Chen. "Selection and Market Reallocation: Productivity Gains from Multinational Production," American Economic Journal: Economic Policy, vol. 10, no. 2, pp. 1-38, 2018.

[8] G.Cette, J. Lopez and J. Mairesse. "Product and Labour Market Regulations, Production Prices, Wages and Productivity," Review of Economics and Institutions, vol. 7 no. 2, Article 1, Mar. 2016. Doi: 10.5202/rei.v7i2.220.

[9] J. Gordon, S. Zhao, and P. Gretton. (2015, Jan.13). On productivity: concepts and measurement, Productivity Commission Staff Research Note, Canberra, February OECD. Defining and Measuring Productivity. [Online]. Available: https://www.oecd.org/sdd/productivity-stats/40526851.pdf. Accessed on: May 19, 2018.

[10] R. B. Moulton. (2018, Jul.15). The Measurement of Output, Prices, and Productivity: What's Changed Since the Boskin Commission? The Brookings institution. [Online]. Available: https://www.brookings.edu/wp-content/uploads/2018/07/Moultonreport-v2.pdf. Accessed on: Aug. 20, 2019.

[11] D. Pacheco, I. Pergher, C. F. Jung and C. S. Caten. "Strategies for increasing productivity in production systems", Independent Journal of Management \& Production, vol. 5, no. 2, pp. 344-359, 2014.

[12] K. Nakamura, S. Kaihatsu and T. Yagi. "Productivity Improvement and Economic Growth", Bank of Japan Working Paper Series, no. 18E-10, 2018.

[13] R. Riley and C. R. Bondibene. "Raising the standard: Minimum wages and firm productivity", National Institute of Economic and Social Research and Centre For Macroeconomics. Niesr discussion paper, no. 449, 2015.

[14] Homenko I. M. "Peculiarities of evaluating the labor motivation level of heavy industry manufacturing enterprise personnel", Economic Annals-XXI, no. 7-8. pp. 39-42, 2013.

[15] Zakharova O. and E. Pridatko. "Factors influencing staff formation processes at industrial enterprises", Nowadays and Future Jobs, vol. 1, iss. 1. pp. 37-47, 2017. 